\title{
The Effects of Combination Treatment Using Phenoxodiol and Docetaxel, and Phenoxodiol and Secreted Frizzled-related Protein 4 on Prostate Cancer Cell Lines
}

\author{
Simon Mahoney ${ }^{1}$, Frank Arfuso ${ }^{1,2}$, Michael Millward ${ }^{3}$ and Arun Dharmarajan ${ }^{1,2^{\star}}$ \\ ${ }^{1}$ School of Anatomy, Physiology and Human Biology, Faculty of Science, The University of Western Australia, Western Australia, Australia \\ ${ }^{2}$ School of Biomedical Sciences, Faculty of Health Sciences, Curtin University, Perth, Western Australia, Australia \\ ${ }^{3}$ School of Medicine and Pharmacology, The University of Western Australia, Crawley, Perth, Australia \\ *Corresponding author: Dr. Arun Dharmarajan, Health Innovation Research Institute, Biosciences Research Precinct, School of Biomedical Science, Curtin University, \\ Perth WA, Australia GPO Box U1987 Perth, Western Australia 6845, Tel: + 6189266 4073; Fax: + 6189266 2342; E-mail: a.dharmarajan@curtin.edu.au
}

Received date: Aug 20, 2014, Accepted date: Nov 20, 2014, Published date: Nov 25, 2014

Copyright: @ 2014 Mahoney S, et al. This is an open-access article distributed under the terms of the Creative Commons Attribution License, which permits unrestricted use, distribution, and reproduction in any medium, provided the original author and source are credited.

\begin{abstract}
Although much progress has been made for the treatment of prostate cancer, patients with advanced prostate cancer still have a poor 5 year survival rate. Current practices for hormone-refractory/castrate resistant, metastatic prostate cancer involve the use of taxanes. Docetaxel, in particular, is being incorporated in numerous current clinical trials either as a single or combination agent against androgen-independent prostate cancer. Combination therapies have the potential to increase the effectiveness of drug treatments while simultaneously increasing quality of life by reducing side effects, lowering effective dosage rates, or by increasing effectiveness of one compound once combined with another.

Using three diverse human prostate cancer cell lines, LNCap, DU145, and PC3, we studied the effect of the novel prostate cancer drug phenoxodiol in combination with docetaxel by utilizing isobolograms, and found that docetaxelinduced cell death was attenuated by co-treatment or pre-treatment of cells with phenoxodiol. This attenuation is associated with the prevention of cells from entering the G2/M phase of the cell cycle where docetaxel is functional in damaging the spindle fibers, and potentially due to p21WAF1 mediated cell survival after docetaxel treatment. We also investigated the use of the Wnt signaling pathway antagonist secreted frizzled-related protein 4 (sFRP4) to increase the effectiveness of phenoxodiol treatment. We found that, through stabilization of the GSK3 $\beta$ molecule, sFRP4 induces degradation of active $\beta$-catenin, which causes an increased sensitivity to isoflavone cytotoxic induction by increasing p21WAF1 expression and decreasing expression of $c-M y c$, Cyclin-D1, and other potent oncogenes. Phenoxodiol induces significant cytotoxicity when combined with a $W n t / \beta$-catenin receptor blocker such as SFRP4. This promotes the concept that combination therapy of a Wnt inhibitor with phenoxodiol might increase the effectiveness of phenoxodiol and give a subset population of prostate cancer sufferers a more effective treatment regime.
\end{abstract}

Keywords: Docetaxel; Phenoxodiol; Isobologram; Signaling frizzledrelated protein 4; Prostate cancer; Wnt signalling; Combination therapy

\section{Introduction}

Advanced prostate cancer has a 5-year survival of only $30 \%$. Historically, chemotherapy has been used with palliative intent but unclear survival benefit for these advanced-stage patients [1]. The lack of curative measures for late stage prostate cancer and the ability to develop resistance to treatment have been linked to the existence of cancer stem cells. The cancer stem cell population acts as an initiator of cancer and exists in low numbers. Cancer stem cells have the ability to acquire resistance upon exposure to treatment, which results in the development of a new population of cells that are now resistant to previously successful treatment $[2,3]$. Current practices for hormonerefractory/castrate resistant, metastatic prostate cancer incorporate the use of taxanes. Docetaxel, in particular, is being incorporated in numerous current clinical trials either as a single or combination agent against androgen-independent prostate cancer, and it is also being investigated for its use as a neoadjuvant or adjuvant agent in hormone sensitive, locally aggressive prostate cancer [4].

Docetaxel and paclitaxel are from a class of anti-cancer agents called taxanes that bind to and stabilize microtubules causing $\mathrm{G} / \mathrm{M}$ cell-cycle arrest and apoptosis [5]. Taxanes have a different mechanism of action from that of any other class of anti-cancer drugs, namely hyper-stabilization of microtubules [1]. Taxanes function by targeting the subunit of the tubulin heterodimer, the key component of cellular microtubules that allows for chromatid separation during the $\mathrm{M}$ cell cycle phase. Although the action and anti-cancer activity of paclitaxel and docetaxel are much the same, key differences exist clinically; docetaxel shows activity in patients with metastatic solid tumors that are resistant to paclitaxel [5].

Combination therapies have the potential to increase the effectiveness of drug treatments while simultaneously increasing quality of life by reducing side effects, lowering effective dosage rates, or by increasing effectiveness of one compound once combined with another. Successful combination therapies that produce an increase in quality of life for patients, even if not associated with life extension, are 
Citation: Mahoney S, Arfuso F, Millward M, Dharmarajan A (2014) The Effects of Combination Treatment Using Phenoxodiol and Docetaxel, and Phenoxodiol and Secreted Frizzled-related Protein 4 on Prostate Cancer Cell Lines. J Carcinog Mutagen 5: 203. doi: $10.4172 / 2157-2518.1000204$

Page 2 of 9

a highly valued outcome of research, even with drugs that do not directly interact $[6,7]$.

To determine an effective combination therapy accurately, the interaction of the two compounds is analyzed and the effectiveness investigated for synergistic, additive, or even interference effects [8]. True synergism is rare as most drugs in combination are additive. Due to clearance rates of these drugs through the body keeping serum levels at an effective concentration means that, in an additive environment, one might not be able to lower effective concentrations, thereby increasing the risk of side effects but theoretically decreasing the length of time treatment must be carried out [9]. Isobolograms are one method of determining effective ranges of drug treatments in combination, because multiple concentrations of drugs can be compared against each other and a profile of effective dose rates can be constructed for the environment being tested. In prostate cancer, surgical intervention, radiotherapy, and chemotherapy are utilized, sometimes in combination, to treat tumors.

Methylation of the sFRP proteins has been suggested as a marker of invasive carcinoma, with a resulting poor prognosis [10]. Apart from $\beta$-catenin degradation, it has been suggested that sFRP4 inhibition of Wnt signaling causes stabilization of GSK3 $\beta$, resulting in p53 activation and associated signaling such as p21WAF1, as well as a decreased invasive potential in androgen-independent prostate cancer cells [11]. sFRP4 has also been indicated to have anti-angiogenic and pro-apoptotic properties in a wide variety of cells [12-14]. Unlike other inhibitors of Wnt signaling, sFRP4 appears to affect both androgendependent and androgen-independent prostate cancer [15].

In this study, we seek to investigate the cytotoxic effects of the prostate cancer treatment docetaxel, and determine a range of treatment concentrations. We also investigated the use of the novel prostate cancer therapeutic phenoxodiol, which has been shown to affect the cell cycle of carcinogenic prostate cells [16,17]. Potential interactions of phenoxodiol and docetaxel across multiple concentrations are investigated, searching for synergistic, additive, or interference effects. We also investigate if any cytotoxic effects are increased through pre-treatment with docetaxel or phenoxodiol and, finally, we try to determine if the $\mathrm{Wnt} / \beta$-catenin antagonist sFRP4, when combined with phenoxodiol, will have an interactive effect.

\section{Materials and Methods}

\section{Cell lines and culture}

The following three human prostate cancer cell lines were used in this study. LNCaP (ATCC: CRL-1740), which represent early stage prostate cancer and are androgen receptor (AR)+; DU145 (ATCC: HTB-81), which represent late stage prostate cancer and are AR-; and PC3 (ATCC: CRL-1435), which represent late stage, highly metastatic prostate cancer and are AR-cells. All cell lines were grown with $10 \%$ FBS, $2 \mathrm{mM}$ L-glutamine and $1 \%$ penicillin/streptomycin media in a $5 \%$ $\mathrm{CO}_{2}$ atmosphere at $37^{\circ} \mathrm{C}$. LNCaP cells were grown in RPMI 1640 media (Gibco) supplemented with $10 \mathrm{mM}$ HEPES, $2.5 \mathrm{~g} / \mathrm{l}$ glucose and $1 \mathrm{mM}$ sodium pyruvate. DU145 cells were grown in MEM with Earle's BSS media (Gibco) supplemented with $1 \mathrm{mM}$ sodium pyruvate and 0.1 mM Non-Essential Amino Acids. PC3 cells were grown in Hams F12K media (Gibco).

\section{Cell proliferation assay and Isobolograms}

The methodology utilized has been discussed previously [18]. Initially, a dose response curve to docetaxel would be needed to determine effective dose rates to use in conjunction with phenoxodiol. Briefly, cells were seeded onto 96-well plates at appropriate rates and incubated for $48 \mathrm{hr}$. Media were then aspirated and replaced with a 10 fold serially diluted concentration of docetaxel from $10 \mu \mathrm{M}$ to $0.1 \mathrm{nM}$, with DMSO as the vehicle control and all samples having an equal concentration of DMSO vehicle added. After $48 \mathrm{hr}$ of treatment, $20 \mu \mathrm{L}$ of MTS dye were added and the cells incubated for 3 hours before absorbance was measured at $492 \mathrm{~nm}$ using a Labsystems Multiscan RC plate reader. Increased absorbance was linked to increased cell metabolism and, therefore, proliferation. No interaction was noted between docetaxel and the MTS dye.

An isobologram was performed between docetaxel and phenoxodiol, and the samples were all balanced for vehicle concentration. Briefly, cells were seeded onto 96 well plates and incubated for $48 \mathrm{hr}$. Afterwards, they had the cell media aspirated and a treatment media applied, containing any combination listed in Table 1 , resulting in 24 different treatments.

\begin{tabular}{|l|l|l|l|l|l|l|}
\hline Drug Name & \multicolumn{5}{|l|}{ Conc. } \\
\hline Phenoxodiol & $0 \mu \mathrm{M}$ & $5 \mu \mathrm{M}$ & $10 \mu \mathrm{M}$ & $30 \mu \mathrm{M}$ & & \\
\hline Docetaxel & $0 \mathrm{nM}$ & $0.1 \mathrm{nM}$ & $1 \mathrm{nM}$ & $5 \mathrm{nM}$ & $10 \mathrm{~nm}$ & $100 \mathrm{nM}$ \\
\hline
\end{tabular}

A list of potential concentration combinations of phenoxodiol and docetaxel in the isobologram, resulting in a final quantity of 24 individual treatment types, all balanced for vehicle control.

The isobologram was performed after $48 \mathrm{hr}$ of incubation with treatment media; $20 \mu \mathrm{L}$ of MTS dye were then added to each well and incubated for 3 hours. Afterwards media absorbance was measured at $492 \mathrm{~nm}$ using a Labsystems Multiscan RC plate reader, with the resulting absorbance indicating cell proliferation rates within the prostate cancer cell lines.

A pre-treatment study was then performed. Briefly, cells were seeded at appropriate rates onto 96 well plates and incubated for $48 \mathrm{hr}$, and then treatment media were applied to each well and incubation occurred for another 24 hours. After 24 hours, a set of 96 well plates had $20 \mu \mathrm{L}$ of MTS dye added, were incubated for 3 hours, and absorbance was measured at $492 \mathrm{~nm}$ on a plate reader. The other plates had the addition of new treatment compounds added to appropriate wells, i.e. some cells had exposure to 24 hours of $30 \mu \mathrm{M}$ phenoxodiol, and then 24 hours of exposure to $100 \mathrm{nM}$ docetaxel and $30 \mu \mathrm{M}$ phenoxodiol in combination. This tested for potential induction of pre-treatment sensitivity. After $48 \mathrm{hr}$ of total treatment with the initial compound concentration, the remaining 96 well plates had $20 \mu \mathrm{L}$ of MTS dye added and were incubated for 3 hours, followed by measurement of absorbance at $492 \mathrm{~nm}$ on a plate reader.

Finally, a Wnt antagonist and phenoxodiol treatment study was performed. Briefly, cells were seeded into 96 well plates at appropriate rates and incubated for $48 \mathrm{hr}$, after which cells were treated with varying concentrations of purified sFRP4 protein up to $500 \mathrm{pg} / \mathrm{mL}$, which was combined with $30 \mu \mathrm{M}$ phenoxodiol treatment. Vehicle consisted of PBS and DMSO respectively. Following $48 \mathrm{hr}$ of exposure to treatment, cells had $20 \mu \mathrm{L}$ of MTS dye added and were incubated for 3 hours before absorbance was measured at $492 \mathrm{~nm}$ on a plate reader. 
Citation: Mahoney S, Arfuso F, Millward M, Dharmarajan A (2014) The Effects of Combination Treatment Using Phenoxodiol and Docetaxel, and Phenoxodiol and Secreted Frizzled-related Protein 4 on Prostate Cancer Cell Lines. J Carcinog Mutagen 5: 203. doi: $10.4172 / 2157-2518.1000204$

Page 3 of 9

\section{Results}

Docetaxel is a common treatment for early and late stage prostate cancer, and is highly cytotoxic as a cell microtubulin stabilizer, causing G2 phase cell cycle blockage in replicating cells by damaging the mitotic spindle [1,5]. As phenoxodiol is able to affect the cell cycle $[16,17]$, a series of experiments were run to determine potential synergy, additivity, interference, or lack of interaction between each compound.
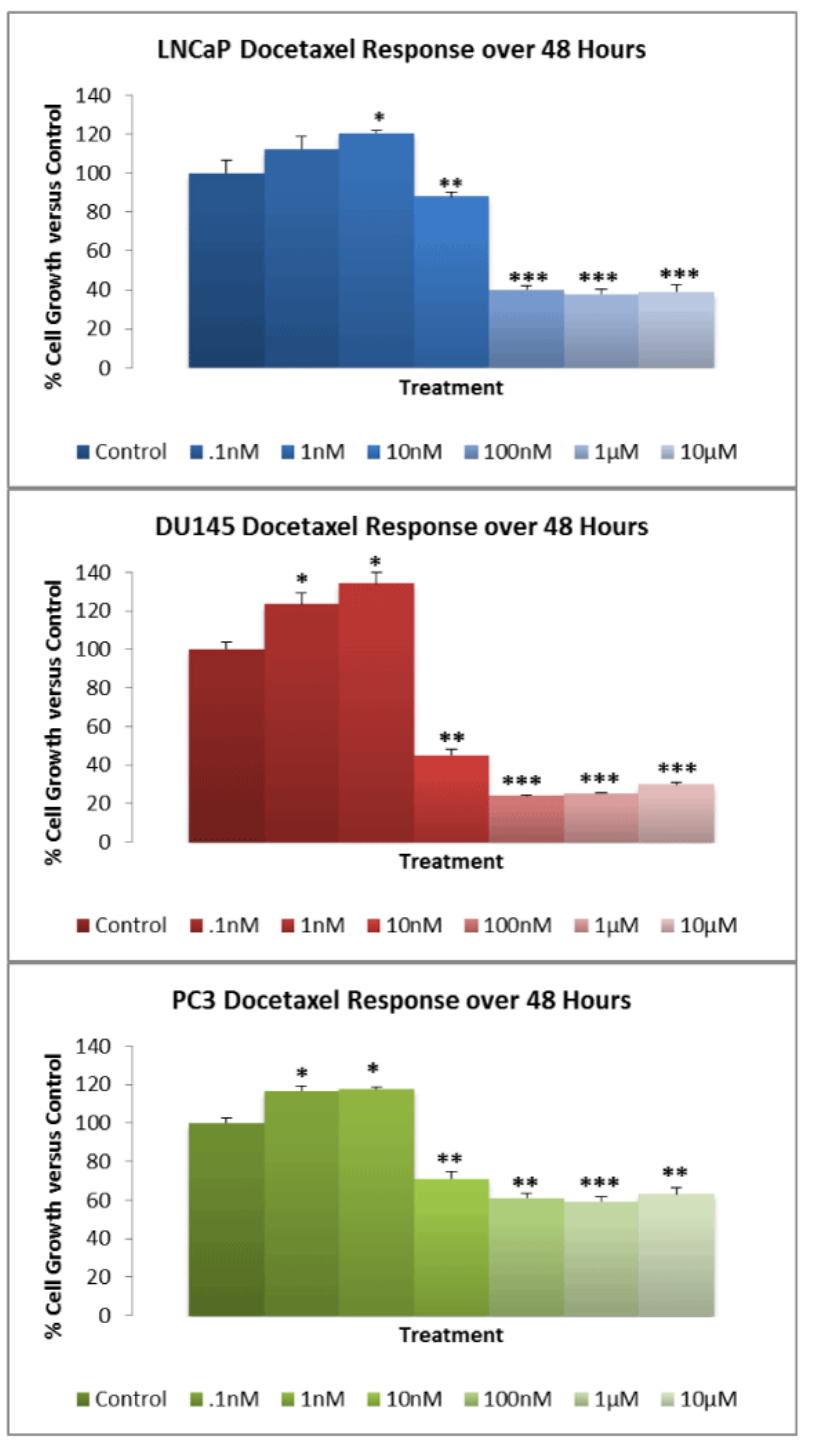

Figure 1: Docetaxel response curve measured after $48 \mathrm{hr}$ of treatment. LNCaP, DU145, and PC3 cell proliferation was determined using an MTS assay following $48 \mathrm{hr}$ docetaxel treatment at various doses.* indicates significance relative to control after $48 \mathrm{hr} .{ }^{* *}$ indicates significance relative to control and ${ }^{*}$ groups after $48 \mathrm{hr}$. ${ }^{* *}$ indicates significance relative to control and ${ }^{\star},{ }^{* *}$ groups after $48 \mathrm{hr}$.
Figure 1 demonstrates the cell proliferation rates of prostate cancer cell lines after $48 \mathrm{hr}$ of treatment with 10 fold dilutions of docetaxel spanning $0.1 \mathrm{nM}$ to $10 \mu \mathrm{M}$ concentrations. LNCaP cells exhibited a significant increase in cell proliferation versus DMSO vehicle control after treatment with $1 \mathrm{nM}$ docetaxel $(\mathrm{p} \leq 0.001)$. LNCaP cells treated with $10 \mathrm{nM}, 100 \mathrm{nM}, 1 \mu \mathrm{M}$, and $10 \mu \mathrm{M}$ concentrations all exhibited a significant decrease in proliferation versus control ( $\mathrm{p}=0.033, \mathrm{p} \leq 0.001$ for the last 3). While the $100 \mathrm{nM}, 1 \mu \mathrm{M}$, and $10 \mu \mathrm{M}$ concentrations were not significantly different to each other, they were all significantly decreased over the $10 \mathrm{nM}$ docetaxel concentration ( $\mathrm{p} \leq 0.001$ for all).

DU145 cells had a similar pattern of response to phenoxodiol treatment with $0.1 \mathrm{nM}$ and $1 \mathrm{nM}$ doses significantly increasing cell proliferation versus control ( $\mathrm{p} \leq 0.001$ for all). The $10 \mathrm{nM}, 100 \mathrm{nM}, 1$ $\mu \mathrm{M}$, and $10 \mu \mathrm{M}$ concentrations exhibited a significant decrease in proliferation versus control ( $\mathrm{p} \leq 0.001$ for all). There was no significant difference detected between $100 \mathrm{nM}, 1 \mu \mathrm{M}$, and $10 \mu \mathrm{M}$ docetaxel treatments but all three were significantly decreased with respect to the $10 \mathrm{nM}$ treatment ( $\mathrm{p} \leq 0.001$ for all).

PC3 cells exhibited a similar trend with $0.1 \mathrm{nM}$ and $1 \mathrm{nM}$ docetaxel treatments significantly increasing cell proliferation versus control ( $\mathrm{p}$ $\leq 0.001$ for both), and $10 \mathrm{nM}, 100 \mathrm{nM}, 1 \mu \mathrm{M}$, and $10 \mu \mathrm{M}$ docetaxel concentrations significantly decreasing proliferation versus control ( $\mathrm{p}$ $\leq 0.001$ for all). Only the $1 \mu \mathrm{M}$ docetaxel concentration was found to be significantly decreased versus $10 \mathrm{nM}$ and $100 \mathrm{nM}$ concentrations $(p=0.042)$. All three cell lines exhibited a significant decrease in proliferation in response to high concentrations of docetaxel, as such the $100 \mathrm{nM}$ dose of docetaxel was chosen as the lowest effective dose over $48 \mathrm{hr}$ of treatment.

Phenoxodiol has exhibited the ability to induce G1/S phase cell cycle arrest, while docetaxel's published method of action is to inhibit the cell cycle at the M phase, resulting in G2 phase arrest [5,16]. After determining the minimum effective concentration dose, an isobologram was performed to look for interaction between phenoxodiol (PXD) and docetaxel (DOC) using varying concentrations of each. Figure 2 demonstrates an isobologram analysis of phenoxodiol and docetaxel treatments over $48 \mathrm{hr}$, with a total of 24 individual treatments all standardized to DMSO vehicle control in LNCaP cells. Isobolograms determine interference, synergy, and additively with significant interference effects indicated in the follow graphs. Additive effects were evident throughout the isobologram but, while there was a significant decrease in cell proliferation rate versus control $(0 \mu \mathrm{M}$ PXD, $0 \mathrm{nM}$ DOC) over most populations, there was a significant increase in proliferative rate versus $100 \mathrm{nM}$ docetaxel only for that time point $(\mathrm{p}=0.014)$, indicating that the $5 \mu \mathrm{M}$ phenoxodiol treatment inhibited the effectiveness of $100 \mathrm{nM}$ docetaxel concentration. These data provide evidence for phenoxodiol interfering with LNCaP cell docetaxel treatment at a specific concentration combination. 
Citation: Mahoney S, Arfuso F, Millward M, Dharmarajan A (2014) The Effects of Combination Treatment Using Phenoxodiol and Docetaxel, and Phenoxodiol and Secreted Frizzled-related Protein 4 on Prostate Cancer Cell Lines. J Carcinog Mutagen 5: 203. doi: $10.4172 / 2157-2518.1000204$

Page 4 of 9

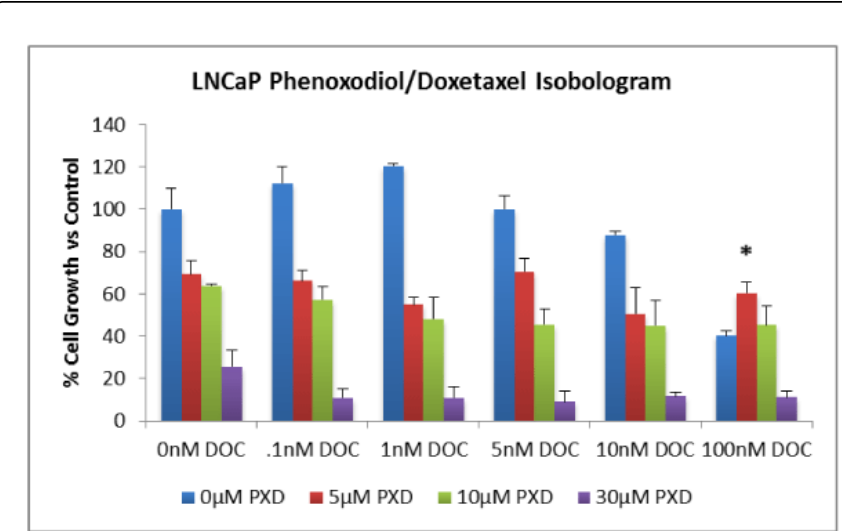

Figure 2: LNCaP phenoxodiol / docetaxel isobologram measured after $48 \mathrm{hr}$ of treatment. LNCaP cell proliferation was determined using an MTS assay following $48 \mathrm{hr}$ docetaxel plus phenoxodiol treatment at various doses and combinations. ${ }^{*}$ indicates significant increase in proliferation relative to $(0 \mu \mathrm{M}$ PXD, $100 \mathrm{nM}$ DOC) treatment after $48 \mathrm{hr}$.

Figure 3 demonstrates an isobologram analysis of phenoxodiol and docetaxel treatments over $48 \mathrm{hr}$, with a total of 24 individual treatments all standardized to DMSO vehicle control in DU145 cells. Additive effects were evident throughout the isobologram but, while there was a significant decrease in cell proliferation rate versus control $(0 \mu \mathrm{M}$ PXD, $0 \mathrm{nM}$ DOC) over most populations, the indicated samples displayed a significant increase in proliferative rate versus $100 \mathrm{nM}$ docetaxel only for that time point $(5 \mu \mathrm{M}$ PXD $\mathrm{p} \leq 0.001,10 \mu \mathrm{M}$ PXD $\mathrm{p}=0.015)$, indicating that the $5 \mu \mathrm{M}$ and $10 \mu \mathrm{M}$ concentrations of phenoxodiol inhibited the effectiveness of a $100 \mathrm{nM}$ docetaxel concentration. These data provide evidence for phenoxodiol interfering with DU145 cell docetaxel treatment at a specific concentration combination.

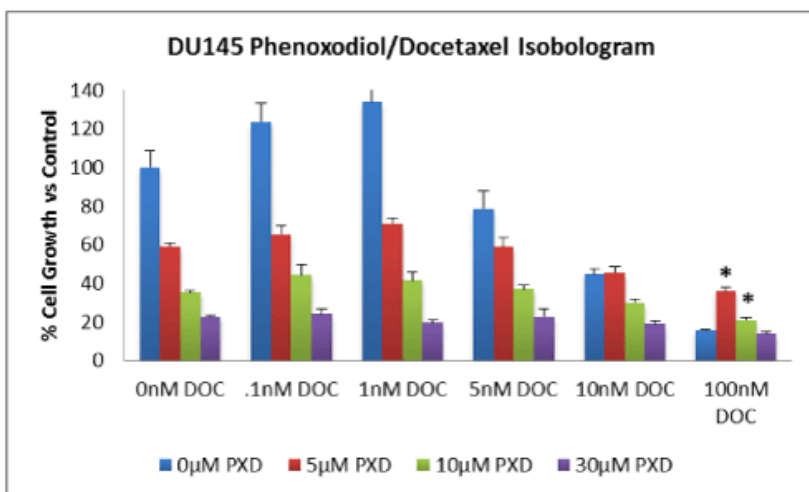

Figure 3: DU145 phenoxodiol / docetaxel isobologram measured after $48 \mathrm{hr}$ of treatment. DU145 cell proliferation was determined using an MTS assay following $48 \mathrm{hr}$ docetaxel plus phenoxodiol treatment at various doses and combinations. ${ }^{*}$ indicates significant increase in proliferation relative to $(0 \mu \mathrm{M}$ PXD, $100 \mathrm{nM}$ DOC) treatment after $48 \mathrm{hr}$.

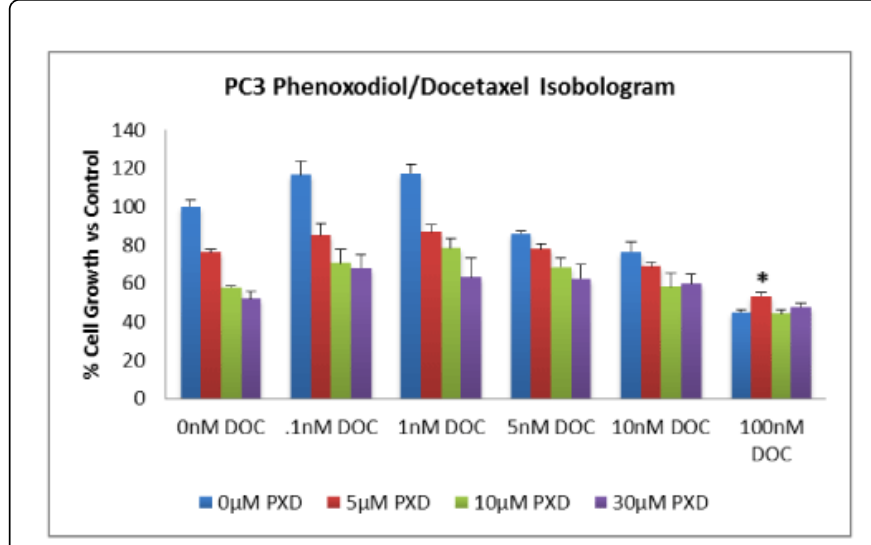

Figure 4: PC3 phenoxodiol / docetaxel isobologram measured after $48 \mathrm{hr}$ of treatment. PC3 cell proliferation was determined using an MTS assay following $48 \mathrm{hr}$ docetaxel plus phenoxodiol treatment at various doses and combinations. ${ }^{*}$ indicates significant increase in proliferation relative to $(0 \mu \mathrm{M} \mathrm{PXD}, 100 \mathrm{nM}$ DOC $)$ treatment after $48 \mathrm{hr}$.

Figure 4 demonstrates an isobologram analysis of phenoxodiol and docetaxel treatments over $48 \mathrm{hr}$, with a total of 24 individual treatments all standardized to DMSO vehicle control in PC3 cells. Additive effects were evident throughout the isobologram but, while there was a significant decrease in cell proliferation rate versus control ( $0 \mu \mathrm{M}$ PXD, $0 \mathrm{nM}$ DOC) over most populations, the indicated samples displayed a significant increase in proliferative rate versus $100 \mathrm{nM}$ docetaxel only for that time point $(\mathrm{p}=0.015)$, indicating that the $5 \mu \mathrm{M}$ phenoxodiol treatment inhibited the effectiveness of $100 \mathrm{nM}$ docetaxel only concentration. These data provide evidence for phenoxodiol interfering with PC3 cell docetaxel treatment at a specific concentration combination.

Following the isobologram results, a more in depth investigation of potential sensitization needed to be performed with pre-treatment of the cells with phenoxodiol or docetaxel and then subsequent addition of the remaining agent. Figure 5 demonstrates a combination therapy treatment of $10 \mu \mathrm{M}$ phenoxodiol and $100 \mathrm{nM}$ docetaxel in prostate cancer cells over 24 and $48 \mathrm{hr}$, with two samples receiving 24 hours solo drug treatment and then the next 24 hours of combined treatment. LNCaP cells exhibited a significant decrease in proliferation versus control over 24 hours in the $10 \mu \mathrm{M} \operatorname{PXD}(\mathrm{p}=0.0089)$ and combination $(\mathrm{p}<0.001)$ treatments, while combination therapy was also significantly lower than the $10 \mu \mathrm{M}$ PXD treatment $(\mathrm{p}=0.0096)$. LNCaP cells exhibited a significant decrease in proliferation versus control over $48 \mathrm{hr}$ when $10 \mu \mathrm{M}$ PXD $(\mathrm{p}<0.001)$, combination $(\mathrm{p}<0.001)$, and 48Hr PXD $(\mathrm{p}<0.001)$ treatments were used. The 100 $\mathrm{nM}$ DOC $(\mathrm{p}<0.05)$ and $48 \mathrm{hr}$ DOC $(\mathrm{p}=0.0035)$ were all significantly decreased in proliferation versus $48 \mathrm{hr}$ PXD as well as $10 \mu \mathrm{M}$ PXD combination and control treatments. Lastly, $48 \mathrm{hr}$ DOC was also significantly decreased versus $100 \mathrm{nM}$ DOC $(\mathrm{p}=0.022)$. 
Citation: Mahoney S, Arfuso F, Millward M, Dharmarajan A (2014) The Effects of Combination Treatment Using Phenoxodiol and Docetaxel, and Phenoxodiol and Secreted Frizzled-related Protein 4 on Prostate Cancer Cell Lines. J Carcinog Mutagen 5: 203. doi: $10.4172 / 2157-2518.1000204$

Page 5 of 9

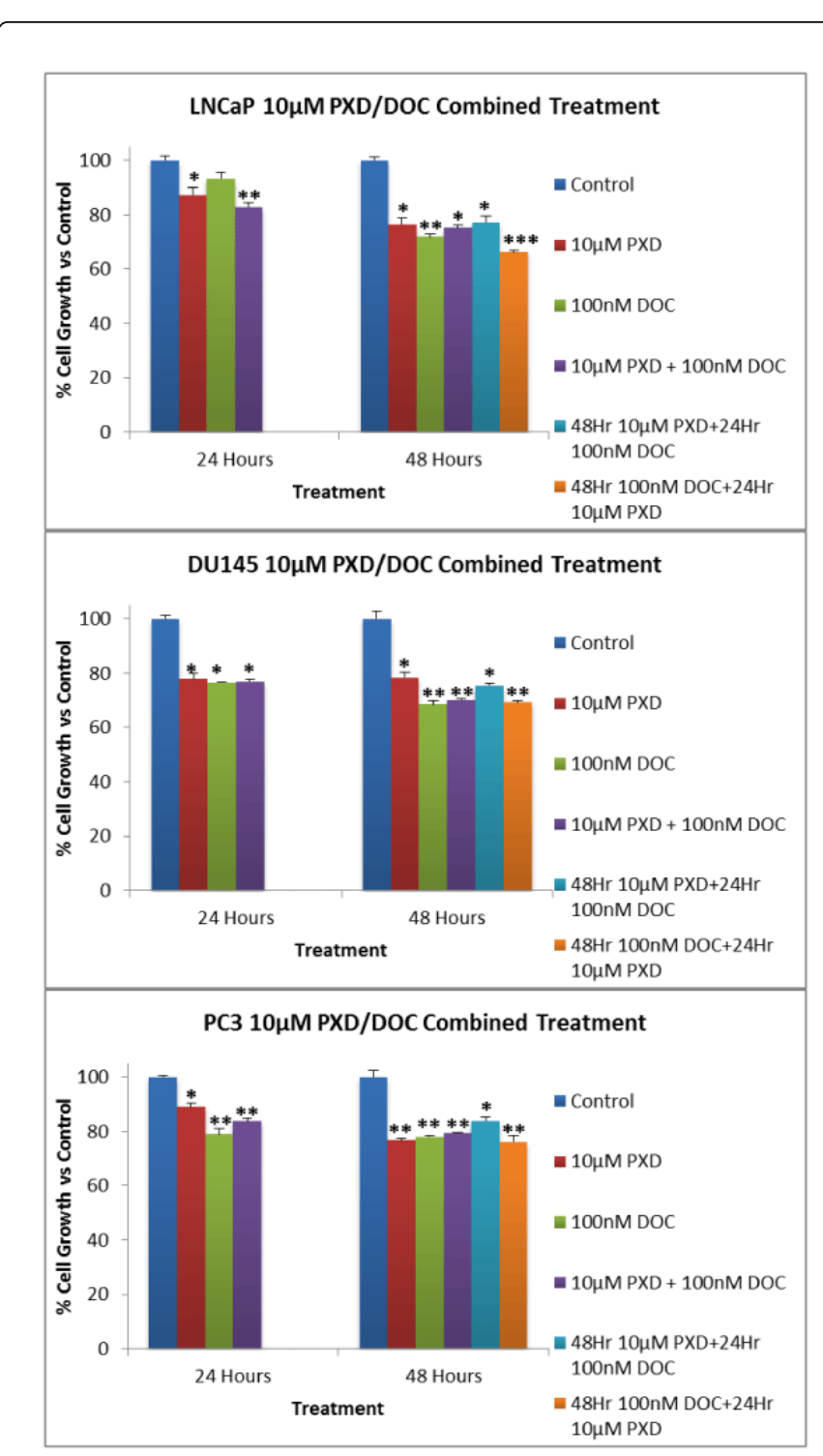

Figure 5: $10 \mu \mathrm{M}$ phenoxodiol 100nm docetaxel combination therapy measured after $48 \mathrm{hr}$ of treatment. LNCaP, DU145, and PC3 cell proliferation was determined using an MTS assay following $48 \mathrm{hr}$ $10 \mu \mathrm{M}$ phenoxodiol and $100 \mathrm{~nm}$ docetaxel treatment. ${ }^{*}$ indicates significance relative to control for that time point. ${ }^{* *}$ indicates significance relative to control and ${ }^{*}$ groups for that time point. ${ }^{* * *}$ indicates significance relative to control, ${ }^{\star}$ and ${ }^{\star *}$ groups.

DU145 cells exhibited a significant decrease in proliferation over 24 hours with $10 \mu \mathrm{M}$ PXD $(\mathrm{p}<0.001), 100 \mathrm{nM}$ DOC $(\mathrm{p}<0.001)$, and combination $(\mathrm{p}<0.001)$ treatments. After $48 \mathrm{hr}$, DU145 cells exhibited significantly decreased proliferation versus control in $10 \mu \mathrm{M}$ PXD $(\mathrm{p}<0.001)$ and $48 \mathrm{hr}$ PXD $(\mathrm{p}<0.001)$ treatments but exhibited no significant difference between each other, while $100 \mathrm{nM}$ DOC $(\mathrm{p}=0.022)$, combination $(\mathrm{p}=0.027)$, and $48 \mathrm{Hr}$ DOC $(\mathrm{p}=0.019)$ treatments were all significantly decreased versus $48 \mathrm{Hr}$ PXD as well as $10 \mu \mathrm{M}$ PXD and control.
PC3 cells exhibited a significant decrease in proliferation versus control after 24 hours of treatment with $10 \mu \mathrm{M}$ PXD ( $<<0.001), 100$ nM DOC $(\mathrm{p}<0.001)$, and combination $(\mathrm{p}<0.001)$ treatments, while 100 $\mathrm{nM}$ DOC $(\mathrm{p}=0.0072)$ and combination $(\mathrm{p}=0.024)$ treatments were also significantly decreased versus $10 \mu \mathrm{M}$ PXD. Following the trend set by LNCaP and DU145 cells, PC 3 cells exhibited a significant decrease in proliferation versus control over $48 \mathrm{hr}$ after treatment with $48 \mathrm{hr}$ PXD $(\mathrm{p}<0.0011)$, while $10 \mu \mathrm{M}$ PXD $(\mathrm{p}=0.0062), 100 \mathrm{nM}$ DOC $(\mathrm{p}=0.0041)$, combination $(p=0.0026)$, and 48 hr DOC $(p=0.0029)$ exhibited significantly decreased proliferation versus $48 \mathrm{hr} \mathrm{PXD}$ as well as control.

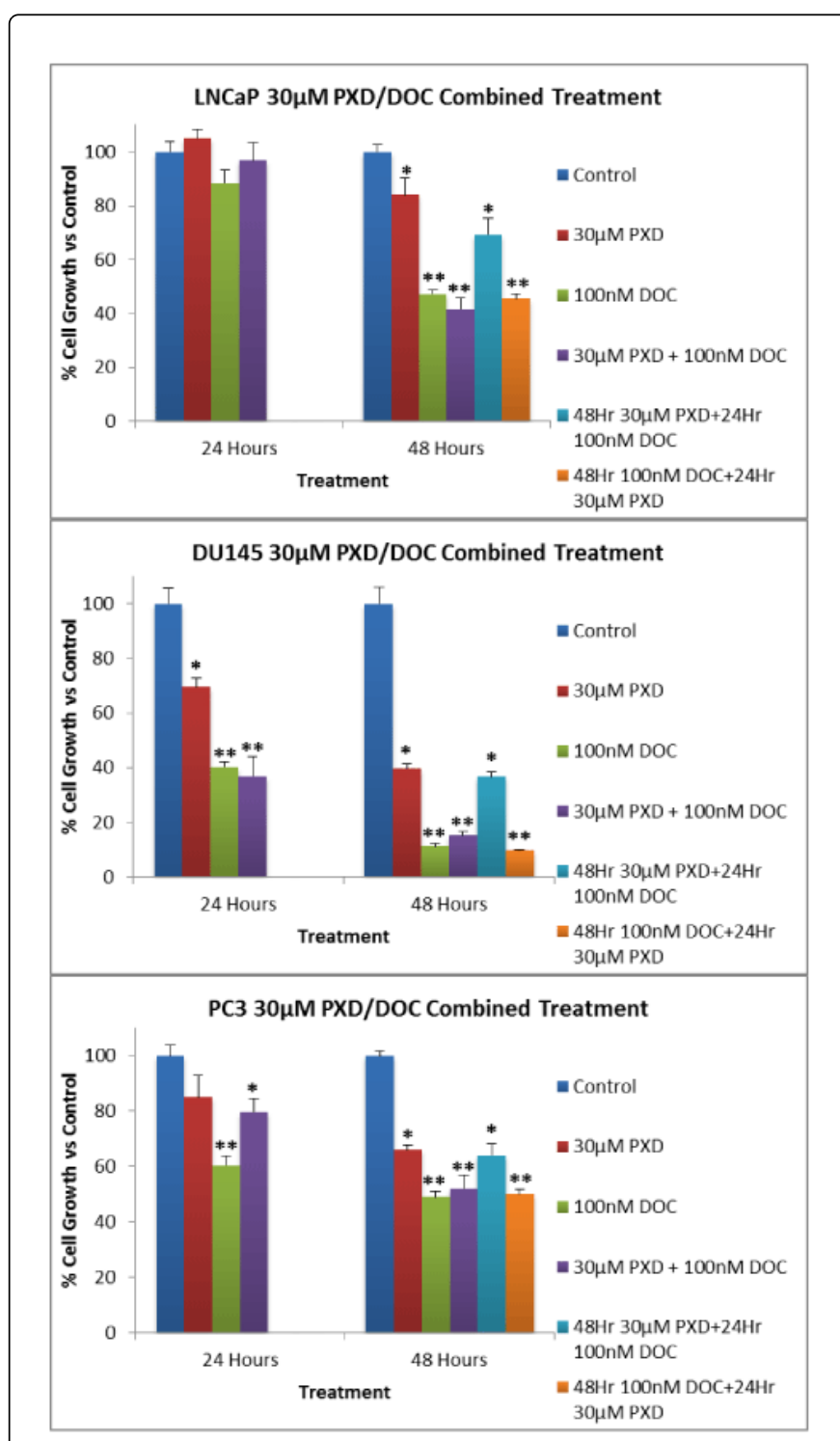

Figure 6: $30 \mu \mathrm{M}$ phenoxodiol 100nm docetaxel combination therapy measured after $48 \mathrm{hr}$ of treatment. LNCaP, DU145, and PC3 cell proliferation was determined using an MTS assay following $48 \mathrm{hr} 30 \mu \mathrm{M}$ phenoxodiol and $100 \mathrm{~nm}$ docetaxel treatment. ${ }^{*}$ indicates significance relative to $\mathrm{DMSO} / \mathrm{PBS}$ vehicle control for that time point. ${ }^{*}$ indicates significance relative to control and ${ }^{*}$ groups for that time point. 
Citation: Mahoney S, Arfuso F, Millward M, Dharmarajan A (2014) The Effects of Combination Treatment Using Phenoxodiol and Docetaxel, and Phenoxodiol and Secreted Frizzled-related Protein 4 on Prostate Cancer Cell Lines. J Carcinog Mutagen 5: 203. doi: $10.4172 / 2157-2518.1000204$

Page 6 of 9

Figure 6 indicates a combination therapy treatment of $30 \mu \mathrm{M}$ phenoxodiol and $100 \mathrm{nM}$ docetaxel in prostate cancer cells over 24 and $48 \mathrm{hr}$, with two samples receiving 24 hours solo drug treatment then the next 24 hours of combined treatment. LNCaP cells did not exhibit a significant change in proliferation versus control over 24 hours. LNCaP cells exhibited a significant decrease in proliferation versus control over $48 \mathrm{hr}$, when $30 \mu \mathrm{M}$ PXD and $48 \mathrm{hr}$ PXD treatments were used $(\mathrm{p}<0.05, \mathrm{p}<0.033)$. The $100 \mathrm{nM}$ DOC $(\mathrm{p}=0.012)$, combination $(\mathrm{p}=0.0092)$, and $48 \mathrm{hr}$ DOC $(\mathrm{p}=0.0090)$ were all significantly decreased in proliferation versus $48 \mathrm{hr}$ PXD, as well as $30 \mu \mathrm{M}$ PXD and control treatments.

DU145 cells exhibited a significant decrease in cell proliferation versus control in $30 \mu \mathrm{M}$ PXD $(\mathrm{p}<0.0034), 100 \mathrm{nM}$ DOC $(\mathrm{p}<0.001)$, and combination $(\mathrm{p}<0.001)$, with both $100 \mathrm{nM}$ DOC $(\mathrm{p}<0.001)$ and combination $(\mathrm{p}<0.005)$ therapy exhibiting further decreased proliferation versus $30 \mu \mathrm{M}$ PXD. A similar trend occurred in DU145 cells as in LNCaP, with $30 \mu \mathrm{M}$ PXD $(\mathrm{p}<0.001)$ and $48 \mathrm{hr}$ PXD $(\mathrm{p}<0.001)$ significantly decreased in proliferation versus control but exhibiting no significant difference between each other, while $100 \mathrm{nM}$ DOC, combination, and $48 \mathrm{hr}$ DOC treatments were all significantly decreased versus $48 \mathrm{hr}$ PXD $(\mathrm{P}<0.001$ for all $)$ as well as $30 \mu \mathrm{M}$ PXD and control.

Finally, PC3 cells exhibited a significant decrease in cell proliferation versus DMSO vehicle control over 24 hours for $100 \mathrm{nM}$ DOC $(\mathrm{p}<0.001)$ and combination therapy $(\mathrm{p}<0.017)$, with $100 \mathrm{nM}$ DOC also being significantly decreased versus $30 \mu \mathrm{M}$ PXD $(\mathrm{p}<0.0021)$ and combined treatment $(\mathrm{p}<0.015)$. Over $48 \mathrm{hr}$ the trend displayed by LNCaP and DU145 continued, PC3 cells were significantly decreased in proliferation over time versus control in the $30 \mu \mathrm{M}$ PXD $(\mathrm{p}<0.001)$ and $48 \mathrm{hr} \operatorname{PXD}(\mathrm{p}=0.001)$ treatments, while $100 \mathrm{nM}$ DOC $(\mathrm{p}=0.0015)$, combination $(\mathrm{p}=0.011)$ and $48 \mathrm{hr}$ DOC $(\mathrm{p}=0.0015)$ were all significantly decreased versus $48 \mathrm{hr}$ PXD as well as $30 \mu \mathrm{M}$ PXD and control. These data suggest that, in all three cell lines, pre-treatment with phenoxodiol for 24 hours before the addition of docetaxel to make a combination with phenoxodiol does not result in a decrease in cell proliferation versus treatment with $30 \mu \mathrm{M}$ phenoxodiol by itself. These data also suggest that combined treatment with phenoxodiol does not increase the activity of docetaxel treatment in comparison to $100 \mathrm{nM}$ only docetaxel treatment over $48 \mathrm{hr}$.

After determining the effects of pre-treatment with Docetaxel, it was decided to test the effect of decreasing Wnt regulatory pathway signaling by addition of sFRP4 whole protein in cell culture in conjunction with phenoxodiol treatment. This was to determine the effects of sFRP4 on prostate cancer cells lines and detect any synergy, additivity, interference, or lack of effect when sFRP4 was used in conjunction with phenoxodiol.

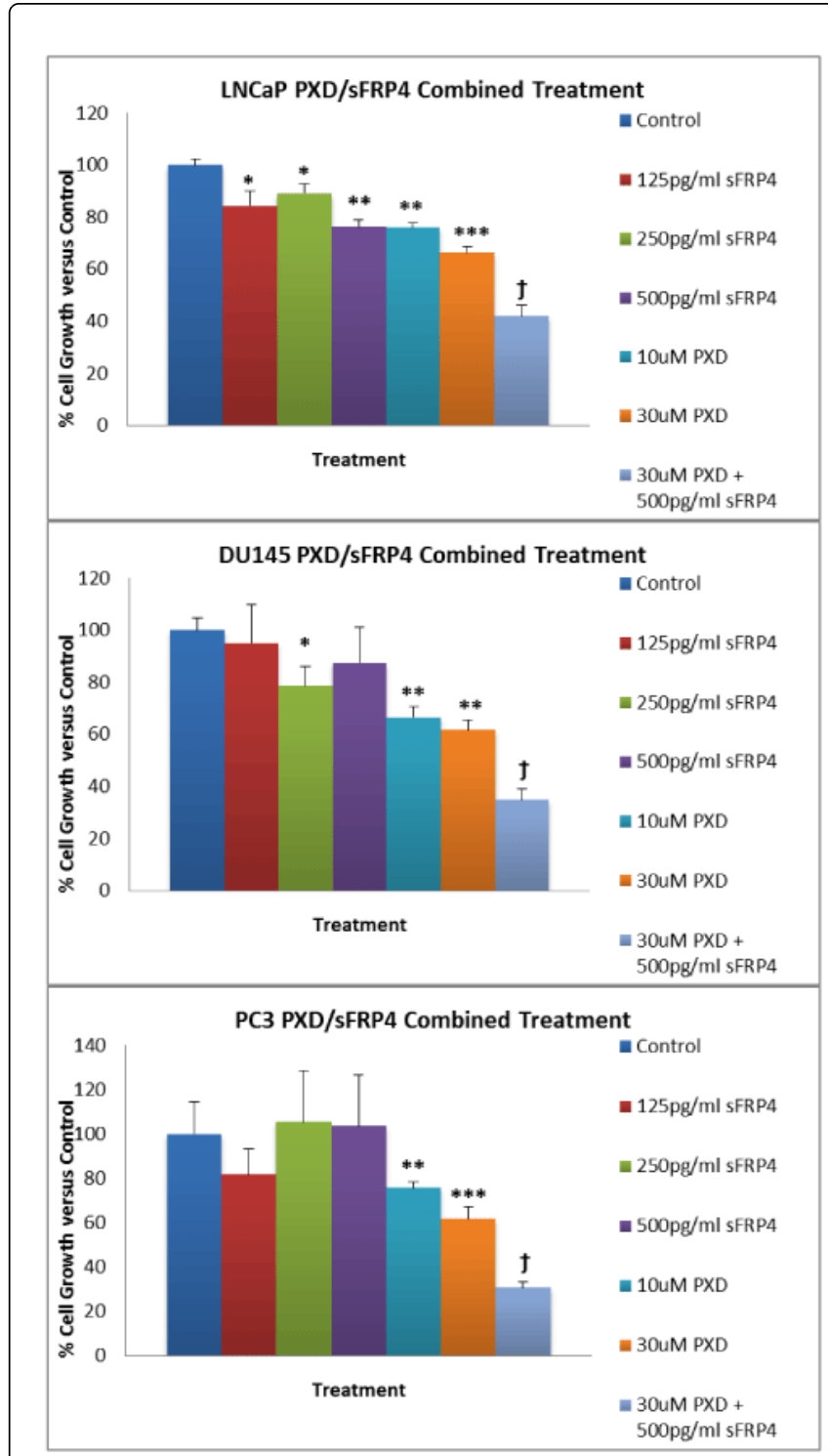

Figure 7: $30 \mu \mathrm{M}$ PXD and $500 \mathrm{pg} / \mathrm{ml}$ sFRP4 protein combination therapy after $48 \mathrm{hr}$. LNCaP, DU145, and PC3 cell proliferation was determined using an MTS assay following $48 \mathrm{hr} 30 \mu \mathrm{M}$ phenoxodiol and $500 \mathrm{pg} / \mathrm{ml}$ sFRP4 treatment. ${ }^{*}$ indicates significance relative to DMSO/PBS vehicle control for that time point. ${ }^{* *}$ indicates significance relative to control and ${ }^{\star}$ groups for that time point. ${ }^{* *}$ indicates significance relative to control, ${ }^{*}$ and ${ }^{* *}$ groups. $f$ is significance relative to all other treatment groups.

Figure 7 indicates the effect of the combination of $500 \mathrm{pg} / \mathrm{mL}$ of sFRP4 and $30 \mu \mathrm{M}$ phenoxodiol treatment over $48 \mathrm{hr}$ on prostate cancer cell lines. Due to the large amount of statistics generated comparing the samples, a general $(p<0.05)$ will be used to indicate significant differences and only specific differences noted. LNCaP cells treated with $125 \mathrm{pg} / \mathrm{mL}$ and $250 \mathrm{pg} / \mathrm{mL}$ sFRP4 were found to exhibit significantly reduced proliferation versus control $(\mathrm{p}<0.05)$. LNCaP cells treated with $500 \mathrm{pg} / \mathrm{mL}$ sFRP4 and $10 \mu \mathrm{M}$ PXD treatments were not determined to be significantly different to each other but were both significantly reduced in comparison to control, $125 \mathrm{pg} / \mathrm{mL}$, and 
Citation: Mahoney S, Arfuso F, Millward M, Dharmarajan A (2014) The Effects of Combination Treatment Using Phenoxodiol and Docetaxel, and Phenoxodiol and Secreted Frizzled-related Protein 4 on Prostate Cancer Cell Lines. J Carcinog Mutagen 5: 203. doi: $10.4172 / 2157-2518.1000204$

Page 7 of 9

$250 \mathrm{pg} / \mathrm{mL}$ sFRP4 treatments $(\mathrm{p}<0.05)$. LNCaP cells treated with 30 $\mu \mathrm{M}$ phenoxodiol exhibited significantly reduced proliferation against control, all sFRP4 concentrations, and $10 \mu \mathrm{M}$ phenoxodiol treatment $(\mathrm{p}<0.05)$; and, finally, the combination of $30 \mu \mathrm{M}$ PXD and $500 \mathrm{pg} / \mathrm{mL}$ sFRP4 proved to significantly reduce proliferation in comparison to control and all other treatments $(\mathrm{p}<0.05)$, with a large improvement over $30 \mu \mathrm{M}$ phenoxodiol only.

DU145 cells exhibited a significant decrease in proliferation versus control with the $250 \mathrm{pg} / \mathrm{mL}$ sFRP4 treatment group $(\mathrm{p}<0.05)$, while neither $125 \mathrm{pg} / \mathrm{mL}$ nor $500 \mathrm{pg} / \mathrm{mL}$ sFRP4 were determined to exhibit any significant changes versus control over $48 \mathrm{hr}$. DU145 cells treated with either $10 \mu \mathrm{M}$ and $30 \mu \mathrm{M}$ phenoxodiol treatments demonstrated a significant decrease in proliferation in comparison to control and all sFRP4 concentrations $(\mathrm{p}<0.05)$ but not versus each other. Finally, the DU145 cells treated with combined sFRP4 and phenoxodiol exhibited a significant decrease in proliferation versus control and the other treatment groups $(\mathrm{p}<0.05)$.

PC3 cells exhibited a significant decrease in cell proliferation versus control with the $10 \mu \mathrm{M}$ phenoxodiol treatment $(\mathrm{p}<0.05)$. None of the sFRP4 treatments were significantly different versus control in the chemoresistant late stage PC3 prostate cancer cells. PC3 cells treated with $30 \mu \mathrm{M}$ phenoxodiol exhibited significantly reduced proliferation versus control, all sFRP4 treatments, and $10 \mu \mathrm{M}$ phenoxodiol $(\mathrm{p}<0.05)$; and finally, similar to the previous two cell lines, PC3 cells treated with $30 \mu \mathrm{M}$ phenoxodiol and $500 \mathrm{pg} / \mathrm{mL}$ sFRP4 demonstrated a significant reduction in proliferation in comparison to control and all other treatments. This study indicates that the combination of $30 \mu \mathrm{M}$ phenoxodiol and $500 \mathrm{pg} / \mathrm{mL}$ sFRP4 results in a significant decrease in cell proliferation across all three cell lines. This indicates that sFRP4 may act as a sensitization agent to the demonstrated cytotoxic effect of phenoxodiol.

\section{Discussion}

Castrate resistant prostate cancer is defined by disease progression despite androgen-deprivation therapy, and may present as one or any combination of a continuous rise in serum levels of prostate-specific antigen (PSA), progression of pre-existing disease, or the appearance of new metastases. Current practices for hormone-refractory/castrate resistant, metastatic prostate cancer incorporate the use of taxanes $[19,20]$. In this study, we investigated the effects of docetaxel on the prostate cancer cell lines LNCaP, DU145, and PC3 to determine effective concentrations that would impact cell proliferation in a measureable manner. We determined that low doses of docetaxel induced cell growth at 0.1 and $1 \mathrm{nM}$ concentrations. Low doses of cytotoxic drugs have been known to initiate oxidative stress in cells, which acts as a mitogenic factor instead of being inhibitory, as the cell easily compensates for the low levels of stimulation, resulting in cell progression through the cell cycle [21]. In all three cell lines, $10 \mathrm{nM}$ and $100 \mathrm{nM}$ doses of docetaxel induced significant decreases in cell proliferation and maximal decreases in proliferation respectively, suggesting potential effective concentrations to utilize in combination with phenoxodiol.

Docetaxel, as with other taxanes, binds to the $\beta$-tublin subunit in microtubulin, promotes polymerization of tubulin, and disrupts microtubule dynamics. As a consequence of microtubulin stabilization, cells become arrested in the G2/M phase and eventually undergo an apoptotic form of cell death. The effects of taxanes may vary depending on cell type and drug concentration. These observations raised the question as to what might be the intracellular signalling machinery that controls the apoptotic differences in response to taxanes in prostate cancer. Studies have shown that apoptosis induced by taxanes involves several apoptotic signal molecules, such as c-Jun $\mathrm{N}$-terminal kinase (JNK), protein kinase A (PKA), c-Raf-1/Ras/Bcl-2, p53/p21, and mitogen-activated protein kinases ERK and p38 [22]. Combined docetaxel and prednisone is currently considered the standard of care for men with castrate resistant prostate cancer, based largely on the simultaneous publication of Tannock [20] and Petrylak [19], where two large randomized controlled trials compared this combination with the previously established standard of mitoxantrone and prednisone. To determine an effective combination therapy accurately, the interaction of two compounds is analyzed and the effectiveness investigated for synergistic, additive, or even interference effects using an isobologram chart where a range of effective doses is compared with each other $[8,9]$.

We next investigated the effects of phenoxodiol combined with docetaxel treatment in an isobologram format over $48 \mathrm{hr}$, with 24 different potential combinations per cell line. We determined that the $5 \mu \mathrm{M}$ phenoxodiol concentration was inducing an interference effect against the $100 \mathrm{nM}$ docetaxel concentration. This was the highest concentration of docetaxel used and the concentration that exhibited the maximal effect of the compound after $48 \mathrm{hr}$ of treatment. All three cell lines had significant interference effects caused by phenoxodiol and docetaxel combination at that concentration, while the DU145 cell line also had the $10 \mu \mathrm{M}$ phenoxodiol dose significantly impacting on the ability of docetaxel to induce cytotoxicity.

To further investigate these phenomena, we evaluated pretreatment combinations in conjunction with complete combinations over $48 \mathrm{hr}$. We investigated the effects of treating the cells with vehicle control, $10 \mu \mathrm{M}$ phenoxodiol, $100 \mathrm{nM}$ docetaxel, or a combination of $10 \mu \mathrm{M}$ phenoxodiol/100nM docetaxel for 24 hours. Following this, the two extra sets of cells received an addition of $10 \mu \mathrm{M}$ phenoxodiol or $100 \mathrm{nM}$ docetaxel, giving them a total of $48 \mathrm{hr}$ of $100 \mathrm{nM}$ docetaxel and 24 hours of phenoxodiol or $48 \mathrm{hr} 10 \mu \mathrm{M}$ phenoxodiol and 24 hours of $100 \mathrm{nM}$ docetaxel. This was also repeated for $30 \mu \mathrm{M}$ phenoxodiol concentrations to determine if the increased cytotoxicity of phenoxodiol would overcome the limited interference that had appeared in the isobolograms. The cell lines indicated that, at all phenoxodiol concentrations after $48 \mathrm{hr}$ of phenoxodiol and 24 hours of docetaxel treatment, there was no significant difference versus phenoxodiol by itself, other than PC3 $10 \mu \mathrm{M}$ samples. This was followed by the result that, at both $10 \mu \mathrm{M}$ and $30 \mu \mathrm{M}$ concentrations, there was a significant increase in proliferation versus $100 \mathrm{nM}$ docetaxel alone, meaning that phenoxodiol had significantly impacted the ability of docetaxel to induce cell arrest at the G2/M stage. While synergism and additivity are the targets of drugs, especially those with different modes of action, phenoxodiol's exhibited ability to induce cell arrest at G1 and S phases of the cell cycle prevents the cells from entering the $\mathrm{G} 2 / \mathrm{M}$ region where docetaxel can be effective [16]. Studies have also indicated that increased expression of p21WAF1 corresponds to an inhibition of docetaxel activity via a p38 dependent signaling pathway, and that cell cycle inhibitors can actually protect the cells from taxane induced cell death during certain periods $[4,23]$. A better understanding of how such mechanisms work at the molecular level may have implications in the rational use of isoflavone/taxane based chemotherapy. 
Citation: Mahoney S, Arfuso F, Millward M, Dharmarajan A (2014) The Effects of Combination Treatment Using Phenoxodiol and Docetaxel, and Phenoxodiol and Secreted Frizzled-related Protein 4 on Prostate Cancer Cell Lines. J Carcinog Mutagen 5: 203. doi: $10.4172 / 2157-2518.1000204$

Page 8 of 9

The canonical $\mathrm{Wnt} / \beta$-catenin signaling pathway promotes transcriptional activity through activation of downstream target genes such as $c-M y c$ and Cyclin-D1 driving cellular proliferation [12,24]. The Wnt ligand target, the frizzled receptor, is overexpressed in prostate cancer, but this overexpression is counterbalanced by the secreted frizzled related protein (sFRP) family, which attempts to suppress AR-mediated transactivation [25]. Methylation of the sFRP proteins has been suggested as a marker of invasive carcinoma, with a resulting poor prognosis [10] and conversely, a total lack of $\beta$-catenin in a prostate cell has also been implicated signaling in metastatic formation [26]. Unlike other inhibitors of Wnt signalling, sFRP4 appears to affect androgen-dependent and androgen-independent prostate cancer [15].

In this study, we investigated the effects of purified sFRP4 in conjunction with phenoxodiol, investigating the published abilities of isoflavones to interact with the Wnt pathway $[27,28]$. Purified protein samples induced a decrease in cell proliferation in LNCaP and D145 cells but not in PC3 cells. All cell lines exhibited a significantly decreased proliferation rate when $500 \mathrm{pg} / \mathrm{mL}$ purified protein was combined with $30 \mu \mathrm{M}$ phenoxodiol over $48 \mathrm{hr}$ of treatment, beyond that of $30 \mu \mathrm{M}$ phenoxodiol by itself. The ability for sFRP4 to interact with frizzled results in a stabilization of the GSK3 $\beta$ molecule, which has been shown to be critical for soy based molecules, such as isoflavones, to induce cell toxicity [28]. This is one manner in which sFRP4 could be sensitizing prostate cancer cells to phenoxodiol treatment; others include the increased expression of p21WAF1 after frizzled activation [29], GSK3 $\beta$ binding to and inactivating IAP members [27], stabilization of p53 expression [12], or even downregulation of the AR through GSK3 $\beta$ stabilization. It has also been shown that sFRP4 is able to chemosensitize cancer cells to conventional chemotherapeutics [30,31]. The Wnt pathway affects many parts of cell homeostasis, and the ability to prevent Wnt ligand activation of $\beta$-catenin and, therefore, stabilize GSK $3 \beta$, results in a signaling situation in which phenoxodiol is more effective.

\section{Conclusion}

We have explored the possibility of combining docetaxel and phenoxodiol as a treatment regime for treating prostate cancer cells by utilizing isobolograms. Our data clearly indicate an antagonistic effect of phenoxodiol on docetaxel's actions. However, we were able to demonstrate a cytotoxic benefit in vitro when phenoxodiol was used in combination with sFRP4, which warrant further investigations in vivo of its potential therapeutic benefit.

\section{Acknowledgements}

$\mathrm{AD}$ is supported by the Cancer Council of Western Australia. The authors have no conflicts of interest in this work.

\section{References:}

1. Montero A, Fossella F, Hortobagyi G, Valero V (2005) Docetaxel for treatment of solid tumours: a systematic review of clinical data. Lancet Oncol 6: 229-239.

2. Reya T, Morrison SJ, Clarke MF, Weissman IL (2001) Stem cells, cancer, and cancer stem cells. Nature 414: 105-111.

3. Trosko JE, Chang CC, Upham BL, Tai MH (2004) Ignored hallmarks of carcinogenesis: stem cells and cell-cell communication. Ann N Y Acad Sci 1028: 192-201.
4. Canfield SE, Zhu K, Williams SA, McConkey DJ (2006) Bortezomib inhibits docetaxel-induced apoptosis via a p21-dependent mechanism in human prostate cancer cells. Molecular cancer therapeutics 5: 2043-2050.

5. Michaud LB, Valero V, Hortobagyi G (2000) Risks and benefits of taxanes in breast and ovarian cancer. Drug Saf 23: 401-428.

6. Kantoff PW, Halabi S, Conaway M, Picus J, Kirshner J, et al. (1999) Hydrocortisone with or without mitoxantrone in men with hormonerefractory prostate cancer: results of the cancer and leukemia group B 9182 study. Journal of clinical oncology 17: 2506-2513.

7. Parente P, Parnis F, Gurney H (2012) Emerging and second line therapies for the management of metastatic castration-resistant prostate cancer: the Australian perspective. Asia Pac J Clin Oncol 8: 31-42.

8. Zhao L, Wientjes MG, Au JL (2004) Evaluation of combination chemotherapy: integration of nonlinear regression, curve shift, isobologram, and combination index analyses. Clinical cancer research: 7994-8004.

9. Tallarida RJ (2006) An overview of drug combination analysis with isobolograms. J Pharmacol Exp Ther 319: 1-7.

10. Ahmad I, Patel R, Liu Y, Singh LB, Taketo MM, et al. (2011) Ras mutation cooperates with $\hat{\mathrm{I}}^{2}$-catenin activation to drive bladder tumourigenesis. Cell Death Dis 2: e124.

11. Horvath LG, Henshall SM, Kench JG, Saunders DN, Lee CS, et al. (2004) Membranous expression of secreted frizzled-related protein 4 predicts for good prognosis in localized prostate cancer and inhibits PC3 cellular proliferation in vitro. Clinical cancer research 10: 615-625.

12. Watcharasit P, Bijur GN, Zmijewski JW, Song L, Zmijewska A, et al. (2002) Direct, activating interaction between glycogen synthase kinase-3beta and p53 after DNA damage. Proc Natl Acad Sci U S A 99: 7951-7955.

13. Fox S, Dharmarajan A (2006) WNT signaling in malignant mesothelioma. Front Biosci 11: 2106-2112.

14. Muley A, Majumder S, Kolluru GK, Parkinson S, Viola H, et al. (2010) Secreted frizzled-related protein 4: an angiogenesis inhibitor. Am J Pathol 176: 1505-1516.

15. Horvath LG, Lelliott JE, Kench JG, Lee CS, Williams ED, et al. (2007) Secreted frizzled-related protein 4 inhibits proliferation and metastatic potential in prostate cancer. Prostate 67: 1081-1090.

16. Aguero MF, Venero M, Brown DM, Smulson ME, Espinoza LA (2010) Phenoxodiol inhibits growth of metastatic prostate cancer cells. Prostate 70: 1211-1221.

17. Seo YJ, Kim BS, Chun SY, Park YK, Kang KS, et al. (2011) Apoptotic effects of genistein, biochanin-A and apigenin on LNCaP and PC-3 cells by $\mathrm{p} 21$ through transcriptional inhibition of polo-like kinase-1. J Korean Med Sci 26: 1489-1494.

18. Mahoney S, Arfuso F, Rogers P, Hisheh S, Brown D, et al. (2012) Cytotoxic effects of the novel isoflavone, phenoxodiol, on prostate cancer cell lines. J Biosci 37: 73-84.

19. Petrylak DP, Tangen CM, Hussain MH, Lara PN Jr, Jones JA, et al. (2004) Docetaxel and estramustine compared with mitoxantrone and prednisone for advanced refractory prostate cancer. N Engl J Med 351: 1513-1520.

20. Tannock IF, de Wit R, Berry WR, Horti J, Pluzanska A, et al. (2004) Docetaxel plus prednisone or mitoxantrone plus prednisone for advanced prostate cancer. N Engl J Med 351: 1502-1512.

21. Minelli A, Bellezza I, Tucci A, Rambotti MG, Conte C, et al. (2009) Differential involvement of reactive oxygen species and nucleoside transporters in cytotoxicity induced by two adenosine analogues in human prostate cancer cells. The Prostate 69: 538-547.

22. Wang R, Lin F, Wang X, Gao P, Dong K, et al. (2008) Suppression of Bcl$\mathrm{xL}$ expression by a novel tumor-specific RNA interference system inhibits proliferation and enhances radiosensitivity in prostatic carcinoma cells. Cancer chemotherapy and pharmacology 61: 943-952.

23. Gan L, Wang J, Xu H, Yang X (2011) Resistance to docetaxel-induced apoptosis in prostate cancer cells by p38/p53/p21 signaling. Prostate 71: 1158-1166. 
Citation: Mahoney S, Arfuso F, Millward M, Dharmarajan A (2014) The Effects of Combination Treatment Using Phenoxodiol and Docetaxel, and Phenoxodiol and Secreted Frizzled-related Protein 4 on Prostate Cancer Cell Lines. J Carcinog Mutagen 5: 203. doi: $10.4172 / 2157-2518.1000204$

Page 9 of 9

24. Menezes ME, Devine DJ, Shevde LA, Samant RS (2012) Dickkopf1: a tumor suppressor or metastasis promoter? Int J Cancer 130: 1477-1483.

25. Kawano Y, Diez S, Uysal-Onganer P, Darrington RS, Waxman J, et al. (2009) Secreted Frizzled-related protein-1 is a negative regulator of androgen receptor activity in prostate cancer. Br J Cancer 100: 1165-1174.

26. Aaltomaa S, Karja V, Lipponen P, Isotalo T, Kankkunen JP, et al. (2005) Reduced alpha- and beta-catenin expression predicts shortened survival in local prostate cancer. Anticancer research 25: 4707-4712.

27. Li J, Xing M, Zhu M, Wang X, Wang M, et al. (2008) Glycogen synthase kinase 3beta induces apoptosis in cancer cells through increase of survivin nuclear localization. Cancer Lett 272: 91-101.

28. Liss MA, Schlicht M, Kahler A, Fitzgerald R, Thomassi T, et al. (2010) Characterization of soy-based changes in Wnt-frizzled signaling in prostate cancer. Cancer Genomics Proteomics 7: 245-252.
29. Hall CL, Zhang H, Baile S, Ljungman M, Kuhstoss S, et al. (2010) p21CIP-1/WAF-1 induction is required to inhibit prostate cancer growth elicited by deficient expression of the Wnt inhibitor Dickkopf-1. Cancer research 70: 9916-9926.

30. Saran U, Arfuso F, Zeps N, Dharmarajan A (2012) Secreted frizzledrelated protein 4 expression is positively associated with responsiveness to cisplatin of ovarian cancer cell lines in vitro and with lower tumour grade in mucinous ovarian cancers. BMC cell biology 13: 25.

31. Warrier S, Balu SK, Kumar AP, Millward M, Dharmarajan A (2013) Wnt antagonist, secreted frizzled-related protein 4 (sFRP4), increases chemotherapeutic response of glioma stem-like cells. Oncol Res 21: 93-102. 